\title{
$950^{\circ} \mathrm{C}$ 순수헬륨 분위기에서 크리프 파단된 Alloy 617 의 미세구조적 고찰
}

\author{
이경근 ${ }^{\dagger}$ 정수진 · 김대종 · 김우곤 · 박지연 · 김동진 \\ 한국원자력연구원 원자력재료개발부
}

\section{Microstructural Investigation of Alloy 617 Creep-Ruptured in Pure Helium Environment at $950^{\circ} \mathrm{C}$}

\author{
Gyeong-Geun Lee ${ }^{\dagger}$, Sujin Jung, Daejong Kim, Woo-Gon Kim, \\ Ji Yeon Park and Dong-Jin Kim
}

Korea Atomic Energy Research Institute Nuclear Materials Division

(2011년 9월 14일 접수 : 2011년 10월 20일 최종수정 : 2011년 10월 25일 채택)

\begin{abstract}
The very high temperature gas reactor (VHTR) is one of the next generation nuclear reactors for its safety, longterm stability, and proliferation-resistance. The high operating temperature of over $800^{\circ} \mathrm{C}$ enables various applications with high energy efficiency. Heat is transferred from the primary helium loop to the secondary helium loop through the intermediate heat exchanger (IHX). The IHX material requires creep resistance, oxidation resistance, and corrosion resistance in a helium environment at high operating temperatures. A Ni-based superalloy such as Alloy 617 is considered as a primary candidate material for the intermediate heat exchanger. In this study, the microstructures of Alloy 617 crept in pure helium and air environments at $950^{\circ} \mathrm{C}$ were observed. The rupture time in helium was shorter than that in air under small applied stresses. As the exposure time increased, the thickness of outer oxide layer of the specimens clearly increased but delaminated after a long creep time. The depth of the carbide-depleted zone was rather high in the specimens under high applied stress. The reason was elucidated by the comparison between the ruptured region and grip region of the samples. It is considered that decarburization caused by minor gas impurities in a helium environment caused the reduction in creep rupture time.
\end{abstract}

Key words VHTR, helium, Alloy 617, creep, microstructure.

\section{1. 서 론}

초고온가스로(very high temperature reactor, VHTR)는 제 4세대 원자로형 중의 하나로, 안정성, 장기가동성, 핵 비확산성과 경제성을 높인 차세대 원자로이다. $800^{\circ} \mathrm{C}$ 이 상의 높은 가동 온도로 인하여 열효율이 높고 고온 공 정열을 제공할 수 있어, Sulfur-Iodine process 등을 이용 한 수소 생산과 고온이 필요한 제조업 분야에 응용될 수 있다. ${ }^{1)}$ 원자로 내부에서 핵 반응에 의하여 발생한 고온 의 열은 열전달 매체인 헬륨을 통하여 원자로를 통하는 1 차 배관을 순환하게 되고, 중간열교환기(intermediate heat exchanger, IHX)를 통하여 방사성이 없는 2차 헬륨 배관 으로 열전달이 이루어지게 된다. $400^{\circ} \mathrm{C}$ 이하의 가동 온 도를 가지는 일반적인 경수로(light water reactor, LWR) 와 달리 초고온가스로의 환경에서 장시간 사용될 중간

${ }^{\dagger}$ Corresponding author

E-Mail : gglee@kaeri.re.kr (G. G. Lee)
열교환기 재료는 높은 크리프 저항성 및 우수한 크리프 -피로 특성, 그리고 고온의 헬륨 환경에서 상안정성을 유 지하여야 한다. 중간열교환기의 주요 후보재료로는 니켈 계 초합금(Ni-base superalloy)이 고려되고 있으며, 그 중 에서도 Alloy 617이 유력한 후보재료 중 하나이다. ${ }^{2)}$ Alloy 617은 고용강화형 가단합금(wrought alloy)으로 1970년대 부터 널리 도입되었으며, $\mathrm{Mo}, \mathrm{Cr}, \mathrm{Co}$ 과 같은 고용 강화 원소로 인하여 고온에서 크리프 강도 및 부식 저항성이 우수하고, $\mathrm{Cr}, \mathrm{Al}$ 등이 표면에 보호 산화막을 형성하여 산 화 및 탈탄 저항성이 높아, 구조적 성능이 장시간 지속 될 수 있다. ${ }^{3)}$

고온의 산화 분위기에서 우수한 크리프 성능을 보이는 Alloy 617이지만, 초고온가스로 환경인 고온 헬륨분위기 에서 고온 기계적 성능이 폭넓게 변화하는 사실이 여러 문헌에 보고되었다. ${ }^{4-10)}$ 이는 초고온가스로 헬륨 환경에 존 재하는 미량의 불순물 가스, 즉 $\mathrm{H}_{2}, \mathrm{CO}, \mathrm{CH}_{4}$ 등이 Alloy 617의 산화, 탈탄, 침탄 등을 유발하기 때문으로 알려져 있 다. 이와 관련하여 초고온가스로 환경에서의 Alloy 617의 
기계적 거동에 대한 연구가 다양하게 진행되고 있으며, 한 국에서도 관련 연구가 적극적으로 진행되고 있다. ${ }^{11-16)}$ 현 재 한국에서 추진중인 초고온가스로의 상용화를 위해서 는, ${ }^{17)}$ 헬륨환경에서 기계적 특성 변화에 대한 정밀한 분 석, 특히 미세구조 변화에 대한 체계적인 관찰을 통한 산화 기구를 분석이 필수적이라 할 수 있다.

본 연구에서는 헬륨 분위기에서 장시간 크리프 시험을 수행한 시편의 미세구조를 자세히 관찰하였으며, 크리프 응력에 따른 표면 구조의 변화에 대하여 집중적으로 분 석하였다. 한 크리프 시편 내에서도 응력이 높은 부분 과 낮은 부분을 비교하여, 산화층 및 탈탄층에 미치는 응력의 영향도 관찰하였다.

\section{2. 실험 방법}

본 실험에 사용된 Alloy 617은 Special Metals (Huntington, West Virginia, US)에서 구입한 상용 재료로, $16 \mathrm{~mm}$ 의 두께를 가지는 판재이고 용체화 열처리까지 완료되 었다. Table 1에 제조사로부터 보고된 조성 분석 결과를 나타내었다. 추가적인 열처리 없이 as-received 상태로 크 리프 시편으로 가공되었으며, 게이지 길이가 $36 \mathrm{~mm}$, 직 경이 $6 \mathrm{~mm}$ 인 봉상 형태로 압연방향이 시편의 길이 방 향이 되도록 준비하였다. Fig. 1에 as-received 시편의 전 형적인 미세구조와 조성 분석 결과를 나타내었다. 제조사 의 자료에 따르면 결정립의 크기는 ASTM $3.0(\sim 127 \mu \mathrm{m})$ 이었고, 결정립계를 따라 존재하는 탄화물과 두께 방향에 수직되게 탄화물 층이 존재하는 것을 알 수 있다. 탄화 물을 $\mathrm{TEM}$ 으로 관찰한 결과, 주로 $\mathrm{Cr}$-rich $\mathrm{M}_{23} \mathrm{C}_{6}$ 임을 확 인하였다. 이는 일반적으로 보고되는 Alloy 617의 asreceived 시편의 미세구조와 비슷한 결과이다. ${ }^{12,18)}$

헬륨 분위기용 초고온 크리프 시험장치는 시험편을 밀 폐시키는 석영관과 가열을 위한 전기로가 크리프 장치 에 결합된 구조로, 시험편을 용이하게 탈착 및 부착할 수 있도록 제작하였다. 시험편에서 발생한 미소 변형을 탄 성 변형에 의해 수용할 수 있는 금속 벨로우즈가 석영 관과 pull rod 사이에 있어, 하중의 변동 오차를 줄이며 기밀을 유지하도록 제작하였다. 가스는 유량계를 통하여 공급하였으며, 가스의 흐름은 기포발생장치(bubbler)를 통 하여 확인하였다. Fig. 2에 크리프 시험장치의 주요 부위 와 크리프 시편을 나타내었다. 크리프 시험은 일정 하중

Table 1. Chemical composition of Alloy 617 used in the study.

\begin{tabular}{cccccccc}
\hline Element & $\mathrm{C}$ & $\mathrm{Mn}$ & $\mathrm{Fe}$ & $\mathrm{S}$ & $\mathrm{Si}$ & $\mathrm{Cu}$ & $\mathrm{Ni}$ \\
Wt.\% & 0.08 & 0.11 & 1.49 & 0.001 & 0.06 & 0.08 & 53.16 \\
\hline Element & $\mathrm{Cr}$ & $\mathrm{Al}$ & $\mathrm{Ti}$ & $\mathrm{Co}$ & $\mathrm{Mo}$ & $\mathrm{P}$ & $\mathrm{B}$ \\
Wt.\% & 22.16 & 1.12 & 0.35 & 11.58 & 9.80 & 0.08 & 0.002 \\
\hline
\end{tabular}

(a)
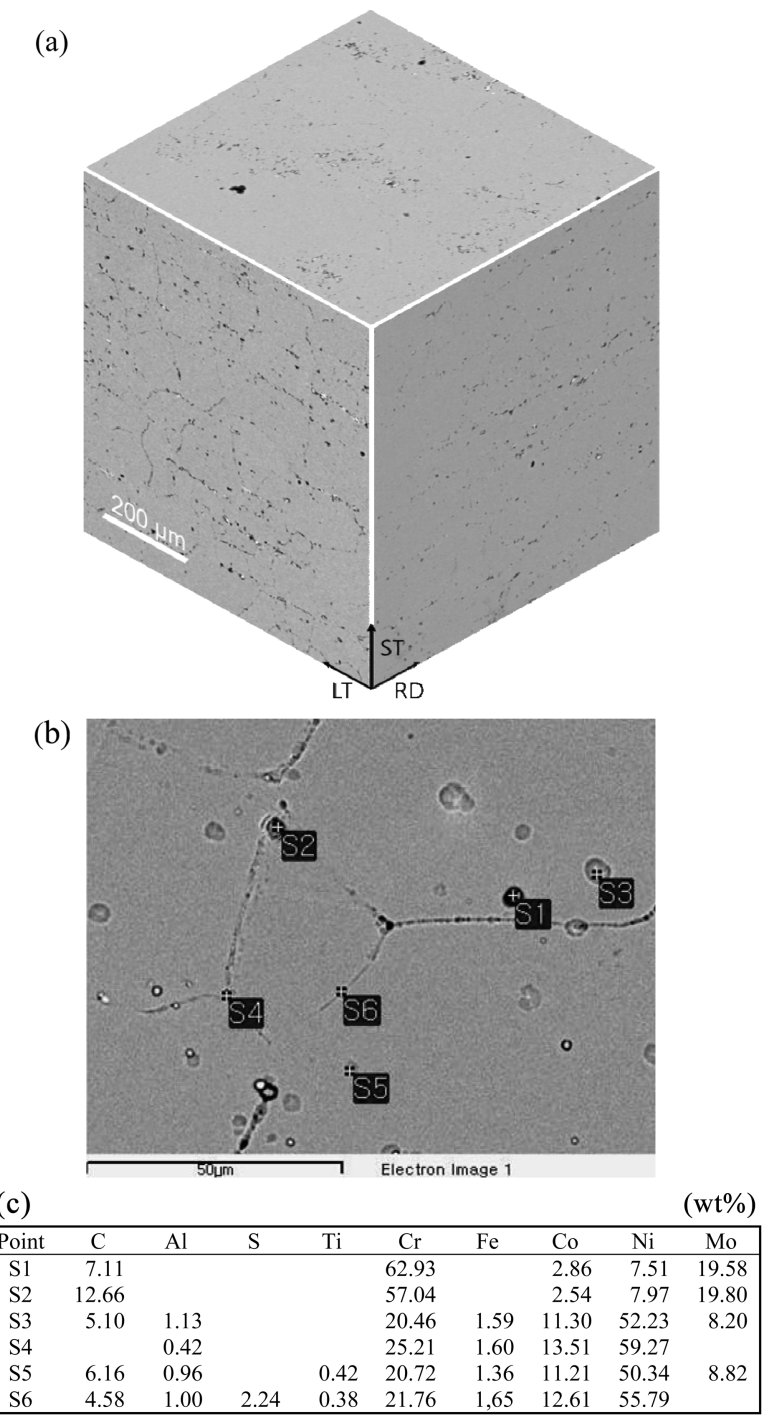

Fig. 1. (a) Three dimensional SEM micrograph, (b) Microstructure of as-received specimen and (c) EDS result of as-received specimen (Fig. 1(b)).

을 이용하였으며, 크리프 시험 전에 목표 온도에서 충분 히 유지시켜 온도의 영향이 줄였다. 온도 측정은 시편 게 이지 부분 근처에 열전대를 이용하였고, $\pm 2^{\circ} \mathrm{C}$ 이내로 편 차를 제어하였다. 크리프 초기하중은 시험하중의 $10 \%$ 를 각 시편마다 동일하게 적용하여 초기 변형률에 의한 오 차가 줄였다. 크리프 시험온도는 $950^{\circ} \mathrm{C}$ 로 고정하였으며, 크리프 응력은 18 35 MPa까지 변화시켰다. 헬륨 가스를 공급하기 전에 3차례 이상 진공 퍼징을 수행하여 시험장 치 내부에 존재할 수 있는 불순물 가스를 제거하였다. 공 급된 헬륨 가스의 조성은 제조사에 따르면, $\mathrm{O}_{2}<1.0 \mathrm{ppm}$, $\mathrm{N}_{2}<5.0 \mathrm{ppm}, \mathrm{H}_{2} \mathrm{O}<1.0 \mathrm{ppm}$ 이었고, 공급 속도는 $20 \mathrm{~cm}^{3}$ / $\min$ 로 유지하였다.

크리프 파단 후 시험장치에서 꺼낸 시편은 파단부 근 처와 그립부로 나누어 연마한 후 미세구조를 SEM으로 관 
(a)
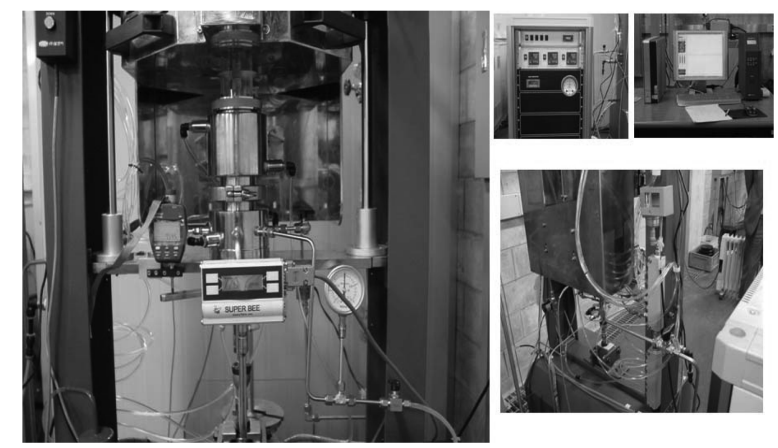

(b)

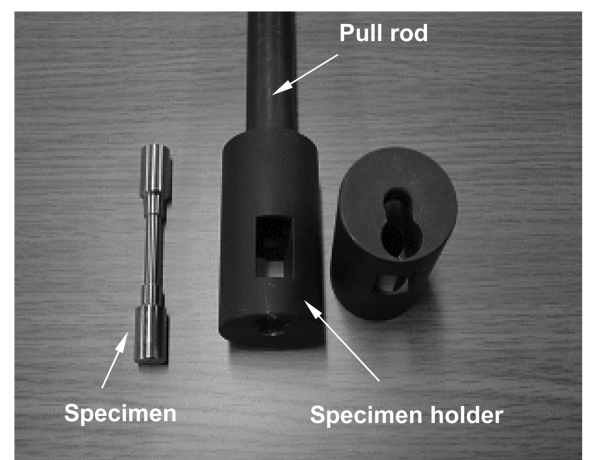

Fig. 2. Photo of helium environment creep test apparatus: (a) creep test machine and test controller and (b) creep specimen and pull rod for creep test.

찰하고, 생성된 산화층 및 탈탄층의 두께를 측정하였다. 이때 생성된 산화층 및 탈탄층의 조성확인은 $\mathrm{EDS}$ 를 사 용하여 분석하였으며, 일부 시편의 경우, EPMA를 통하 여 시편내의 $\mathrm{Cr}$ 의 농도 변화도 관찰하였다.

\section{3. 결과 및 고찰}

\section{1 헬륨 분위기에서 크리프 파단시간의 변화}

헬륨 분위기와 대기 분위기에서 하중 변화에 의한 크 리프 파단시간의 변화를 Fig. 3에 나타내었다. 대기중의 결과는 일반적인 크리프 시험장치를 사용하였다. 크리프 곡선을 분석한 결과, 1 차 크리프와 2 차 크리프 영역은 뚜렷하게 나타나지 않은 반면, 시간에 따라 크리프 속 도가 증가하는 3 차 크리프가 주로 관찰되었다. 이는 철 계 페라이트 재료들에서 보고된 경향과는 구분되는 Alloy 617의 특성이다. ${ }^{19)}$ 헬륨 및 대기 분위기에서 크리프 파단 시간을 비교해 볼 때, 크리프 응력에 따라서 파단 거동 이 달라졌다. 고응력으로 인하여 크리프 파단시간이 짧은 경우에는 헬륨 분위기 시편과 대기 분위기 시편의 파단 시간에 큰 차이가 없었다. 하지만, $20 \mathrm{MPa}$ 이하의 낮은 응력으로 인하여 크리프 시간이 길어질 경우에는, 헬륨 분 위기 시편이 대기 분위기 시편에 비하여 파단시간의 감 소가 두드러졌다. 특히 $18 \mathrm{MPa}$ 시편의 경우, 헬륨 분위
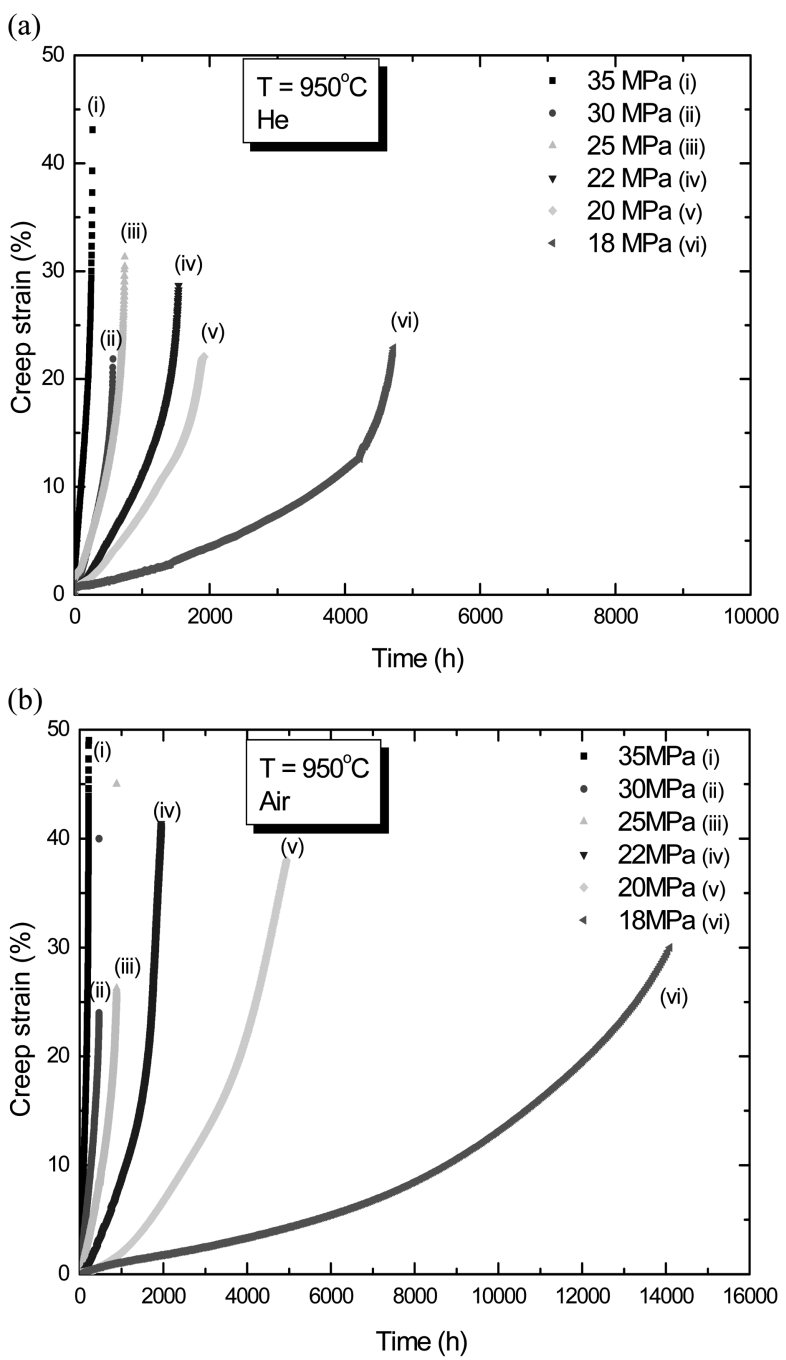

Fig. 3. Creep strain vs. time under various creep stress at $950^{\circ} \mathrm{C}$ in (a) helium environment and (b) air environment.

기 시편의 파단시간은 대기 분위기 시편의 파단시간인 $14099 \mathrm{hr}$ 의 $1 / 3$ 인 $4704 \mathrm{hr}$ 이었다. 이와 같은 헬륨 분위기 에서의 수명 시간의 변화는 헬륨의 조성과 크리프 온도 에 매우 민감하게 변화하는 것으로 알려져 있다. ${ }^{8)}$ 초고 순도 헬륨 환경에서는 Alloy 617의 산화 및 탈탄이 억 제되는 것으로 알려졌지만, 미량의 산소를 포함한 헬륨 환 경의 경우, Cr-oxide, Al-oxide 등의 산화막이 형성되고, 결정립계에 존재하는 $\mathrm{Cr}$ 탄화물 등이 분해되어 기계적 특 성이 낮아진다고 보고되었다.) 본 실험이 수행된 분위기 는 불순물 가스를 고려하지 않은 순수한 헬륨 분위기이 나, 가스 제조과정에서 혼입된 미량의 수분과 산소가 장 시간 크리프 실험 중에 Alloy 617과 반응하여 산화 및 탈탄이 발생한 것으로 보이며, 이로 인하여 크리프 파 단시간이 감소하는 것으로 생각된다. 이에 대한 구체적 인 분석을 위하여 각 시편의 미세구조를 관찰하였다. 

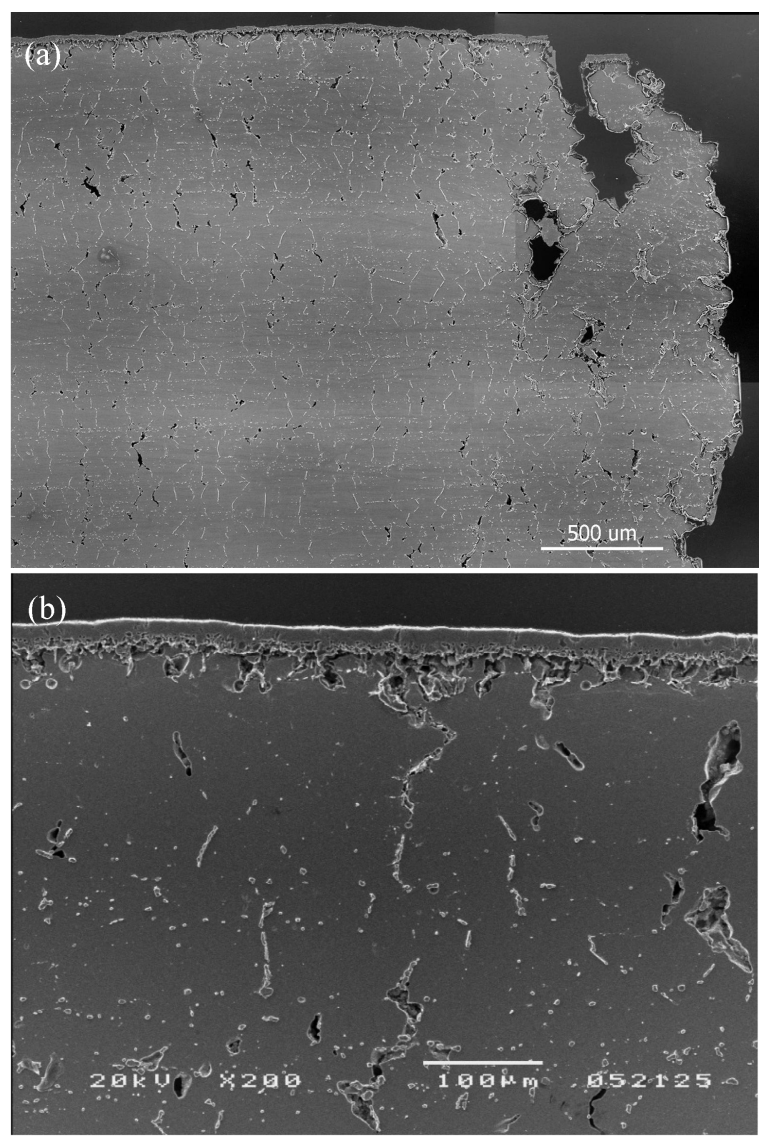

Fig. 4. Microstructure of crept specimen under $20 \mathrm{MPa}$ at $950^{\circ} \mathrm{C}$ in the helium environment. (a) low magnified cross-sectional view and (b) magnified view of the surface of the specimen.

\section{2 헬륨 분위기 크리프 시편의 미세구조}

Fig. 4 에 $950^{\circ} \mathrm{C}$ 헬륨 분위기에서 $20 \mathrm{MPa}$ 로 크리프 시 험한 시편의 단면을 나타내었다. 저배율 사진인 Fig. 4(a) 를 관찰한 결과, 파단면은 주로 결정립계를 따라 형성되 었다. 외부 표면에는 산화층이 형성되었으며, 그 밑으로 탄화물이 보이지 않는 탈탄층이 관찰되었다. 기지내의 탄 화물의 경우, 응력 방향에 수직인 결정립계를 따라 탄화 물들이 주로 분포하였고, 응력 방향에 평행한 방향으로 는 탄화물들이 적게 존재하였다. 이는 $\mathrm{M}_{23} \mathrm{C}_{6}$ 가 응력의 영 향에 민감하게 반응하여, 압축응력이 가해질수록 쉽게 분 해된 후, 인장응력이 있는 쪽으로 확산한다는 Kihara et $\mathrm{al}^{20)}$ 의 보고와 일치하는 결과이다. 크리프 시험으로 결정 립계 사이에서 크리프 cavity가 성장하였고, 이는 3차 크 리프 단계에서 주로 생성된 것으로 보인다. 시편 내부에 응력 방향에 평행되게 존재하는 탄화물 띠는 as-received 시편에서 관찰된 것과 같은 $\mathrm{M}_{23} \mathrm{C}_{6}$ 탄화물이였다. Fig. 4(b)는 표면 근처를 더 높은 배율로 관찰한 결과로, 표 면 반응에 의하여 형성된 미세구조를 확인할 수 있다. 시 편의 표면에는 외부 산화층이 형성되었는데, 주로 $\mathrm{Cr}-$ oxide로 알려져 있다. 외부 산화층 밑에 기지로 침투한

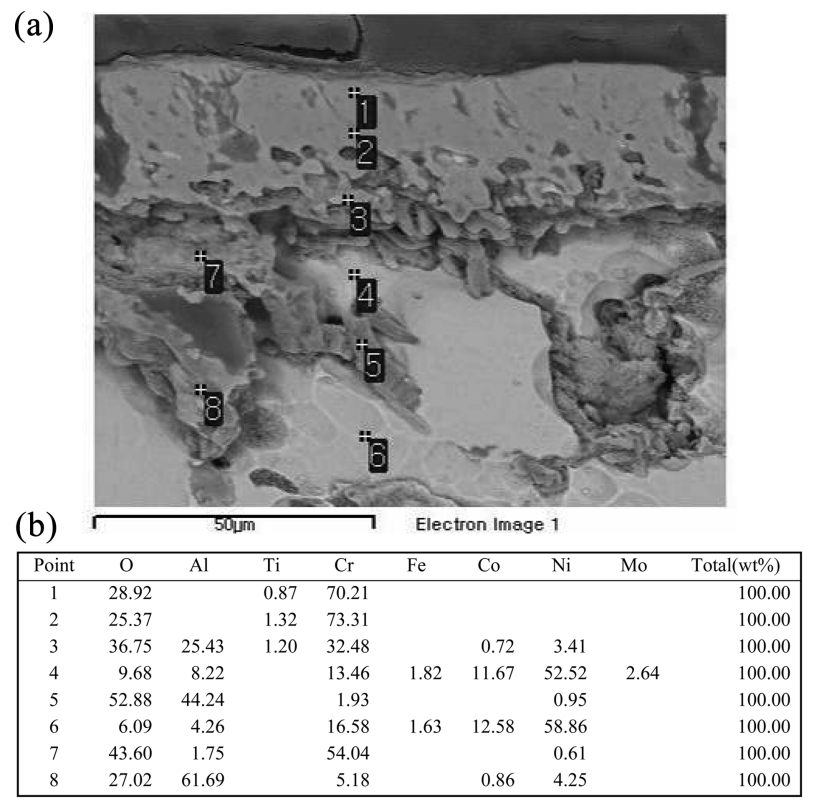

Fig. 5. (a) Back Scattered SEM image and (b) EDS result of crept specimen under $20 \mathrm{MPa}$ at $950^{\circ} \mathrm{C}$ in the helium environment.

내부 산화층이 존재하는데, 이는 Alloy 617 내의 Al과 반응하여 형성된 Al-oxide로 알려져 있으며, 외부에 존 재하는 Cr-oxide와 내부 기지와의 박리를 줄이면서 내부 로의 산소 확산을 돕는 것으로 보고되었다. ${ }^{3)}$ 크리프 응 력에 의하여 표면에서 발생한 균열을 따라, 외부산화층 과 내부 산화층이 기지 내부까지 침투한 곳도 발견할 수 있었다. 결정립계에 존재하였던 $\mathrm{M}_{23} \mathrm{C}_{6}$ 탄화물 등이 사 라진 탈탄층도 뚜렷이 관찰할 수 있다.

Fig. 5는 $20 \mathrm{MPa}$ 의 응력으로 크리프 시험 후 파단된 시편의 단면을 $\mathrm{EDS}$ 를 통하여 분석한 자료이다. 외부산화 층인 $1,2,3$ point에서는 주로 Cr-oxide가 관찰되었고, $\mathrm{Ti}$ 도 검출되었다. Ti의 경우 다른 금속원소에 비하여 열 역학적으로 고온에서 산화가 잘 일어나는 원소로, 본 재 료에서도 외부 산화층에 주로 존재하는 것을 확인하였 다. 내부 산화층인 5,8 point에서는 Al-oxide가 관찰되 었고 주로 판상의 형태로 존재하였다. 기지에 존재하는 $\mathrm{Cr}$ 의 경우, 표면에 가까운 4 point의 $\mathrm{Cr}$ 농도가 중심부 에 가까운 6 point의 $\mathrm{Cr}$ 농도보다 낮았는데, 이는 기지 내에 고르게 존재하였던 $\mathrm{Cr}$ 이 외부 산화층을 형성하기 위하여 표면으로 확산되었기 때문이다.

\section{3 크리프 응력 변화에 따른 시편의 미세구조 비교}

Fig. 6는 헬륨 환경에서 응력을 변화시키며 크리프 실 험한 시편들의 미세구조이다. 각 시편에서 주요 산화층 및 탈탄층의 두께는 크리프 환경에 노출된 시간과 가해 진 크리프 응력, 두 가지 요소의 복합적인 영향을 받게 된다. 따라서 각 시편의 주요 층들은 응력이 없는 상태 
(a)

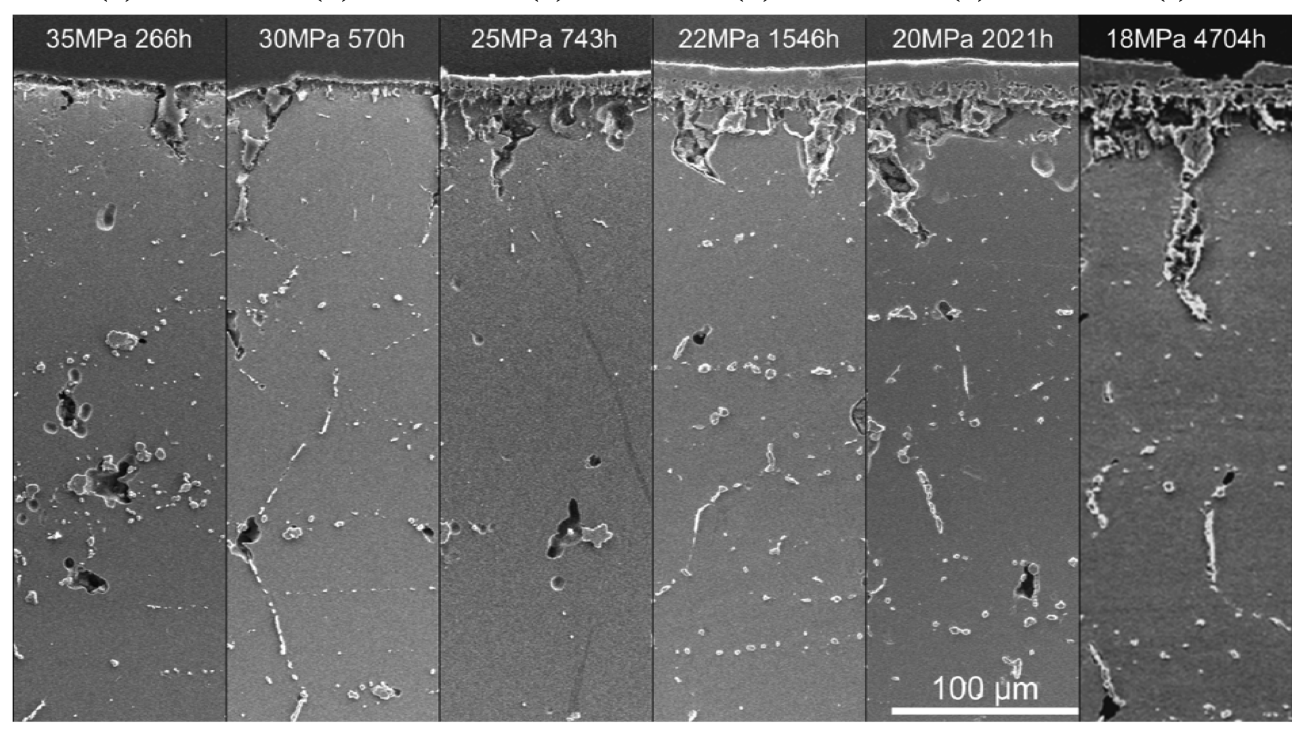

Fig. 6. Microstructures of the surface near the ruptured parts. The creep tests were carried out at $950^{\circ} \mathrm{C}$ in helium environment. Captions in the figures show the applied stress and rupture time of the samples; (a) under $35 \mathrm{MPa}$ in $266 \mathrm{~h}$, (b) under $30 \mathrm{MPa}$ in $570 \mathrm{~h}$, (c) under $25 \mathrm{MPa}$ in $743 \mathrm{~h}$, (d) under $22 \mathrm{MPa}$ in $1546 \mathrm{~h}$, (e) under $20 \mathrm{MPa}$ in $2021 \mathrm{~h}$ and (f) under $18 \mathrm{MPa}$ in $4704 \mathrm{~h}$.

에 비하여 복잡한 거동을 나타내게 된다. 외부 산화층 의 경우, 크리프 응력이 높아 짧은 시간에 파단된 $266 \mathrm{hr}$ 와 $570 \mathrm{hr}$ 시편에서는 산화층의 두께가 얇았고, 이후에 점차 산화층의 두께가 증가하였다. 하지만 $4704 \mathrm{hr}$ 에 파 단된 시편의 경우, 표면이 다른 시편과 달리 매끄럽지 못하고 거친 것을 관찰하였다. 내부 산화층의 경우, 파 단시간의 증가에 따라 점차적으로 증가하였다. 표면에서 균열 또한 시간이 증가할수록 깊게 진행하였고 이를 따

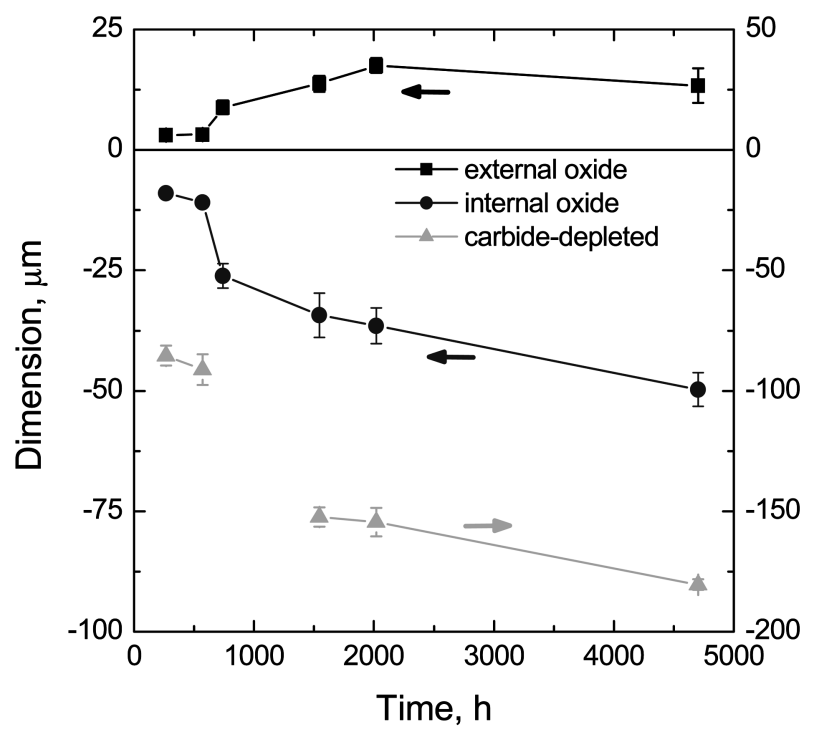

Fig. 7. Evolution of the external oxide thickness, the maximum depth of internal oxide penetration, and the depth of the carbidedepleted zone under various creep stresses at $950^{\circ} \mathrm{C}$ in helium environment.
라서 기지 내부까지 Cr-oxide와 Al-oxide가 침투한 것을 관찰할 수 있었다. 표면에서 탄화물의 제거된 깊이까지 로 정의한 탈탄층은, 외부 산화층 및 내부 산화층과 달 리 크리프 응력이 높은 시편에서 급격하게 깊이가 증가 하였고, 이후 크리프 응력이 작아질수록 완만히 증가하 였다. 각 층의 두께 변화를 Fig. 7에 정리하여 정량적으 로 나타내었다. 외부 산화층의 경우, $266 \mathrm{hr}$ 에 파단된 $35 \mathrm{MPa}$ 시편과 $570 \mathrm{hr}$ 에 파단된 $30 \mathrm{MPa}$ 시편간의 두께 차이는 크게 나타나지 않았다. 이는 시편간의 편차 및 실 험 환경상의 문제로 생각된다. $4704 \mathrm{hr}$ 에 파단된 $18 \mathrm{MPa}$ 크리프 시편의 경우, 외부 산화층의 두께가 오히려 감소 하였고 표준편차가 다른 시편에 비하여 컸다. 내부 산화 층의 침투 깊이는, 전형적인 parabolic 형태를 나타냈다. 탈탄층의 경우, 짧은 시간에 파단된 고응력 크리프 시편 에서 탈탄층 깊이가 산화층에서 측정된 경향보다 더 깊 게 나타났으며, 시간에 따른 증가량이 적었다. $743 \mathrm{hr}$ 에 파 단된 $25 \mathrm{MPa}$ 시편의 경우, 미세구조 상으로 내부 탄화물 관찰이 어려워 결과에 포함시키지 않았다.

응력의 영향을 분리하여 시편의 미세구조를 평가하기 위하여 각 시편에서 상대적으로 낮은 응력을 받았던 크 리프 시편의 그립부 단면을 추가로 관찰하였다. 즉 같은 파단시간을 가지지만, 응력의 효과가 상대적으로 적은 시 편의 미세구조를 관찰함으로써 응력의 영향을 간접적으 로 확인할 수 있다. Fig. 8에 그립부의 미세구조 사진을 정리하였고, Fig. 9에 각 층의 두께 측정 결과를 파단부 에 비교하여 나타내었다.

외부 산화층의 경우, $18 \mathrm{MPa}$ 시편을 제외하고 파단부 
(a)

(b)

(c)

(d)

(e)

(f)

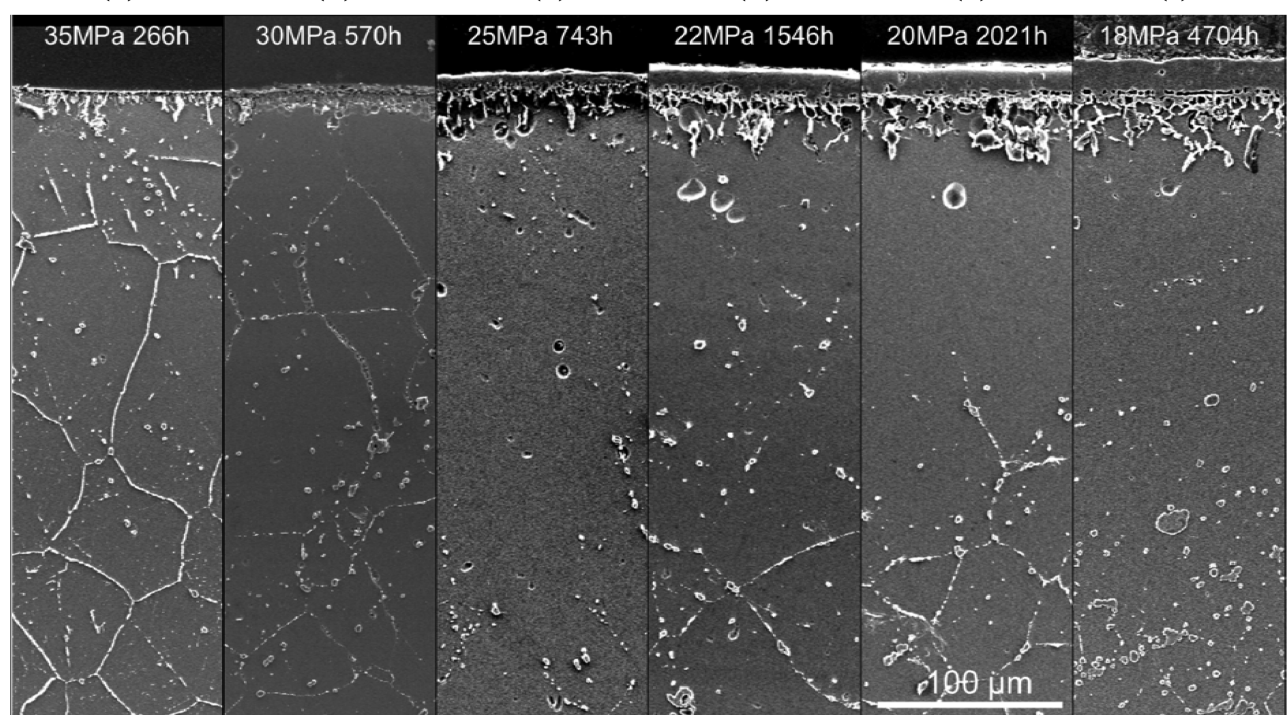

Fig. 8. Microstructures of the surface near the grip parts. The creep tests were carried out at $950^{\circ} \mathrm{C}$ in helium environment. Captions in the figures show the applied stress and rupture time of the samples; (a) under $35 \mathrm{MPa}$ in $266 \mathrm{~h}$, (b) under $30 \mathrm{MPa}$ in $570 \mathrm{~h}$, (c) under $25 \mathrm{MPa}$ in $743 \mathrm{~h}$, (d) under $22 \mathrm{MPa}$ in $1546 \mathrm{~h}$, (e) under $20 \mathrm{MPa}$ in $2021 \mathrm{~h}$ and (f) under $18 \mathrm{MPa}$ in $4704 \mathrm{~h}$.
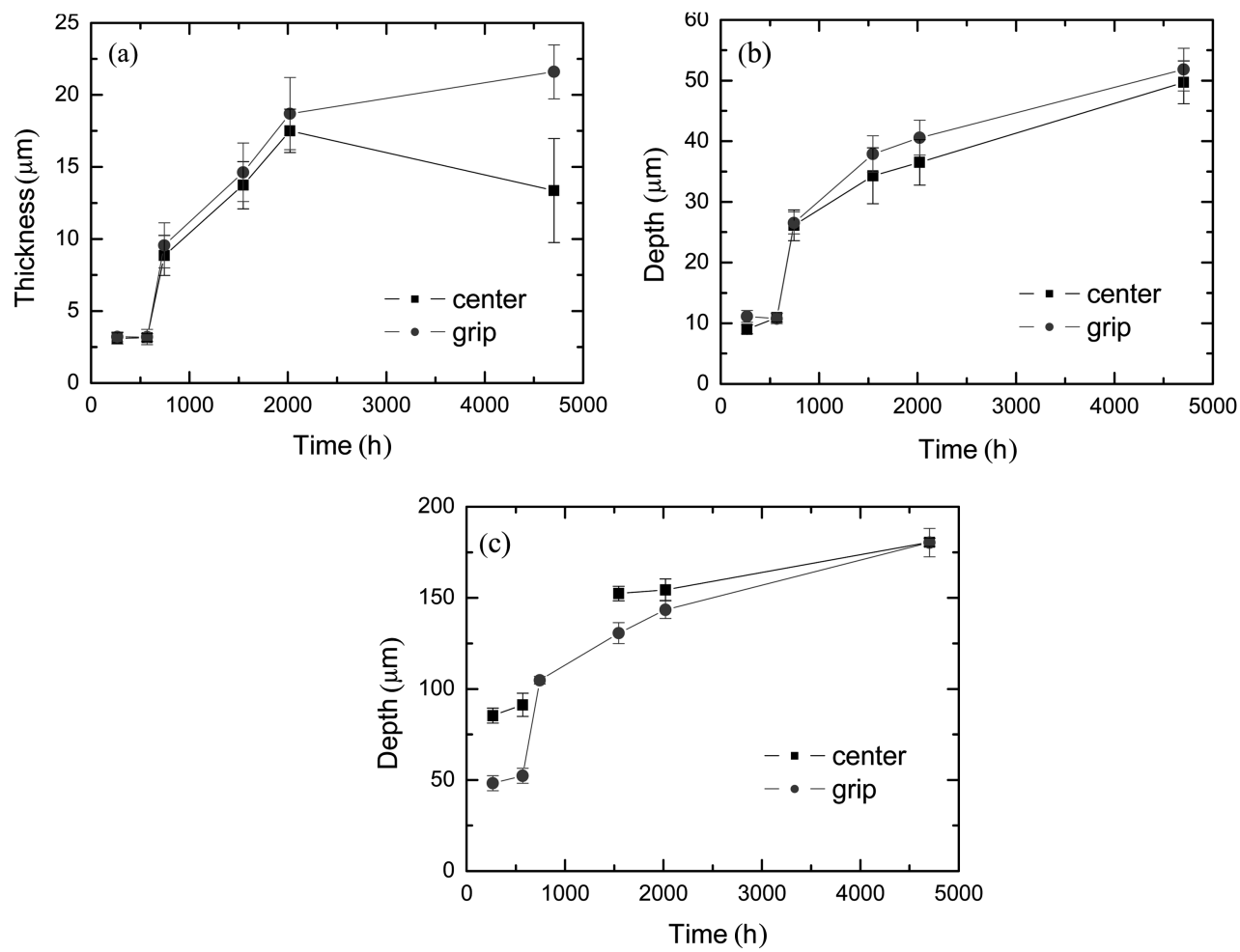

Fig. 9. Comparison between the grip part and rupture part of the crept specimens: (a) external oxide thickness, (b) the maximum depth of the internal oxide penetration and (c) the depth of the carbide-depleted zone.

와 유사한 두께를 나타내었다. $18 \mathrm{MPa}$ 시편의 경우, 그 립에서 산화층의 두께는 매우 두꺼웠으며, 이는 응력이 없 을 경우, 산화시간 증가에 따라서 산화층이 계속적으로 성 장함을 의미한다. 즉, 응력이 존재하는 파단부에서는 외
부 산화층의 박리(delamination)가 발생하여 지속적인 산 화층 성장이 억제되었음을 알 수 있다. 이는 박리가 일 어난 $18 \mathrm{MPa}$ 시편의 표면 산화층을 관찰하여 나타낸 Fig. 10 을 통하여 확인할 수 있다. 


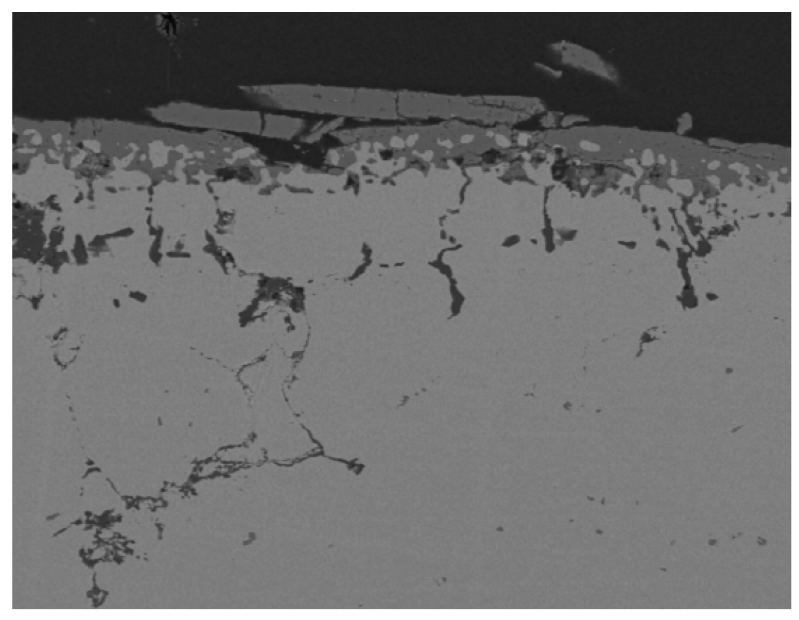

Fig. 10. Microstructure of delaminated $\mathrm{Cr}$-oxide layer in crept specimen under $18 \mathrm{MPa}$.

내부 산화층은 파단부와 그립부에서 큰 차이가 나타나 지 않았다. 이 결과는 크리프 시편에서 발생한 균열에 따른 깊이 변화를 고려하지 않고, 표면으로부터의 내부 산화층이 침투한 길이 만을 비교하였을 때의 결과이다.

탈탄층의 경우, 저응력 시편, 즉 장시간 크리프 시험 된 시편에서는 파단부와 그립부 모두 탈탄층 깊이가 유 사하게 나타났으나, 고응력 시편에서는 그립부에 비하여 파단부에서 탈탄층이 깊게 관찰되었다. 즉, 상대적으로 응 력이 높은 조건에서 $\mathrm{M}_{23} \mathrm{C}_{6}$ 가 계면에서 빠르게 제거된 것
이다. 이는 Fig. 4에서 관찰한 결과와 연관 지어 설명될 수 있다. 즉, 계면에 존재하는 $\mathrm{M}_{23} \mathrm{C}_{6}$ 는 응력이 존재할 경 우, 용해가 발생하며, 특히 고응력이 가해질 경우, 짧은 시간에 분해될 수 있는 것이다. 이를 정량적으로 확인하 기 위하여 기지내의 $\mathrm{Cr}$ 의 농도 분포를 $\mathrm{EPMA}$ 로 측정하 여 Fig. 11에 나타내었다. 저응력으로 장시간 크리프 시 험한 $20,18 \mathrm{MPa}$ 시편의 경우, 표면으로부터 $\mathrm{M}_{23} \mathrm{C}_{6}$ 가 분 해된 깊이와 $\mathrm{Cr}$ 의 depletion이 유사하게 나타났지만, 35 $\mathrm{MPa}$ 의 크리프 시편은 계면에서 사라진 탄화물층의 깊이 와 Cr-depletion 깊이에 차이가 있음을 알 수 있다. 즉 크리프 응력으로 인하여, 계면에 존재하는 $\mathrm{M}_{23} \mathrm{C}_{6}$ 탄화 물이 빠르게 제거된 것을 확인할 수 있다.

계면에 존재하는 $\mathrm{M}_{23} \mathrm{C}_{6}$ 의 농도 감소는 고온에서 결정 립계의 유동을 용이하게 할 수 있고, 표면 균열 전파 및 크리프 cavity의 발생이 촉진할 수 있다. 특히, 헬륨환경 에서 크리프 파단시간이 대기 분위기 보다 짧은 것은, 대 기 분위기의 높은 산소 농도로 인한 치밀한 산화층 발 생과 균열의 빠른 산화로 인한 crack tip blunting 등이 발생하지 않았기 때문으로 사료된다.

본 실험에서 헬륨 내에 존재하였던 미량의 산소와 수 분은 시편의 표면에서 산화 및 탈탄을 유발하였다. 즉, 미량의 불순물 환경이라도 장시간의 크리프 시험에서는 재료의 열화를 유발할 수 있었다. 실제 초고온가스로의 헬륨 환경은 다량의 $\mathrm{H}_{2}, \mathrm{CH}_{4}, \mathrm{CO}, \mathrm{CO}_{2}$ 와 미량의 $\mathrm{O}_{2}$, $\mathrm{H}_{2} \mathrm{O}$ 등의 불순물이 존재하며 높은 유속으로 흐르게 된
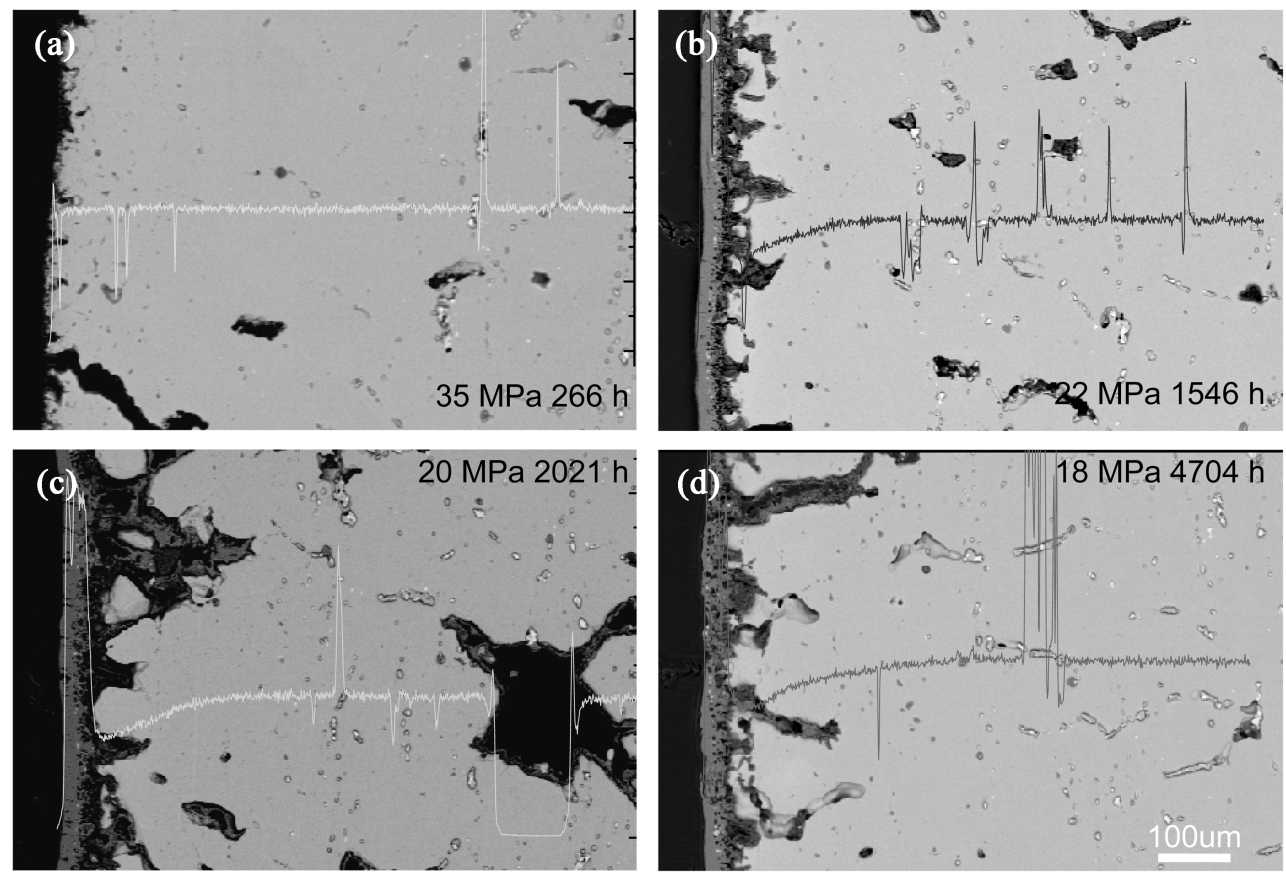

Fig. 11. Cr-concentration profiles of various crept specimens. Captions in the figures show the applied stress and rupture time of the samples; (a) under $35 \mathrm{MPa}$ in $266 \mathrm{~h}$, (b) under $22 \mathrm{MPa}$ in $1546 \mathrm{~h}$. (c) under $20 \mathrm{MPa}$ in $2021 \mathrm{~h}$ and (d) under $18 \mathrm{MPa}$ in $4704 \mathrm{~h}$. 
다. 이와 같은 환경에서 기계적 성질의 변화는 더욱 폭 넓게 달라질 수 있다. 따라서, 이를 고려한 고온 기계적 특성 변화에 대한 지속적인 연구가 Alloy 617의 VHTR 환경에서의 응용에 필요할 것으로 사료된다.

\section{4. 결 론}

$950^{\circ} \mathrm{C}$ 의 헬륨 환경에서 Alloy 617 시편의 크리프 실 험 후 파단된 시편의 미세구조에 대하여 다양한 분석을 진행하였다. 크리프 응력이 높을 경우 파단시간은 헬륨 분위기와 대기 분위기 모두에서 유사하였으나, 낮은 응 력에서는 헬륨에서의 파단시간이 더 짧았다. 파단된 시 편의 표면을 관찰한 결과, $\mathrm{Cr}$-oxide 외부 산화층, $\mathrm{Al}-$ oxide 내부산화층, 그리고 결정립계에 존재하였던 탄화물 이 제거된 탈탄층이 형성되었다. 외부 산화층의 경우, 장 시간 크리프 시편에서 산화층의 박리가 발생하였는데, 이 는 크리프 응력에 의하여 파단부의 산화층 박리가 발생 한 것으로 생각된다. 내부 산화층의 경우, 응력이 집중된 파단부와 응력이 낮은 그립부 모두에서 유사한 침투 깊 이를 나타내었다. 탈탄층의 경우, 크리프 하중에 의한 고 응력이 계면의 탄화물 분해를 촉진하였으며, 이는 그립부 에서의 관찰 결과와 $\mathrm{Cr}$ 의 조성 분석을 통하여 확인할 수 있었다. 기계적 성능의 관점에서 헬륨 내에 존재하는 미 랑의 산소와 수분으로 인한 산화 및 탈탄이 응력 효과 와 결합하여 표면의 미세구조를 변화시켰고, 이를 통하 여 크리프 균열의 전파가 용이해져 헬륨 분위기 크리프 시편의 파단시간을 단축시킨 것으로 예측된다.

\section{감사의 글}

이 연구는 2010년도 정부(교육과학기술부)의 재원으로 한국연구재단의 지원을 받아 수행된 연구임(No. 20100029810).

\section{참 고 문 헌}

1. J. Bouchard and R. Bennett, Nucl. Plant J., 26(5), 42 (2008).

2. W. Ren and R Swimdeman, J. Press. Vess. Tech., 131, 024002 (2009).
3. Special Metals Publication, Number SMC-029, INCONEL Alloy 617 (2005). Special Metals Publication, Number SMC-029, INCONEL Alloy 617, (2005). Special Metals on the web. Retrieved Sep. 10, 2011 from http://www. specialmetals.com/documents/Inconel\%20alloy\%20617. pdf.

4. H. -J. Christ, U. Kunecke, K. Meyer and G. Sockel, Mater. Sci. Eng., 87, 161 (1987).

5. B. Huchtemann, Mater. Sci. Eng., 120-121, 623 (1989).

6. R. H. Cook, Nucl. Tech., 66, 283 (1984).

7. Y. Hosoi and S. Abe, Metall. Mater. Trans., 6A, 1171 (1975).

8. P. S. Shankar and K. Natesan, J. Nucl. Mater., 366, 28 (2007).

9. F. Rouillard, C. Cabet, K. Wolski, A. Terlain, M. Tabarant, M. Pijolat and F. Valdivieso, J. Nucl. Mater., 362, 248 (2007).

10. C. Cabet and F. Rouillard, J. Nucl. Mater., 392, 235 (2009).

11. T. S. Jo, S. -H. Kim, D. -G. Kim, J. Y. Park and Y. D. Kim, Met. Mater. Int., 14(6), 739 (2008).

12. C. Jang, D. Lee and D. Kim, Int. J. Pres. Ves. Pip., 85, 368 (2008).

13. D. Kim, C. Jang and W. S. Ryu, Oxid. Met., 71, 271 (2009).

14. D. -J. Kim, G. -G. Lee, S. W. Kim and H. P. Kim, Corrosion Sci. Tech., 9(4), 164 (2010).

15. D. -J. Kim, G. -G. Lee, S. J. Jeong, W. -G. Kim and J. Y. Park, Nucl. Eng. Technol., 43(5), 429 (2011).

16. H. -C. Kwon, D. -J. Kim, H. P. Kim, J. Y. Park and S. D. Hong, Kor. J. Mater. Res., 21(1), 1 (2011) (in Korean).

17. W. J. Lee, Y. W. Kim and J. Chang, Nucl. Eng. Technol. 41(4), 413 (2009).

18. T. C. Totemeier and H. Tian, Mater. Sci. Eng., 468-470, 81 (2007).

19. W. -G. Kim, S. -N. Yin and G. -H. Koo, Met. Mater. Int., 15(5), 727 (2009).

20. S. Kihara, J. B. Newkirk, A. Ohtomo and Y. Saiga, Metall. Mater. Trans., 11, 1019 (1980). 